\title{
間質性肺炎合併肺癌における治療後急性増悪の検討
}

\author{
磯部和順 1 秦 美暢 $2 \cdot$ 杉野圭史 1 -佐野 剛 1 高井雄二郎 1 ・ \\ 木村一博 $1 \cdot$ 長谷川千花子 $3 \cdot$ 笹本修一 $2 \cdot$ 高木啓吾 $2 \cdot$ 本間 栄 1
}

要旨一一目的．間質性肺炎（interstitial pneumonia：IP）合併肺癌における治療後の IP 急性増悪の臨床像を明らかに する. 方法. 1999 年 6 月〜2007 年 4 月までに加療した肺癌 776 例を対象とし, IP 合併肺癌の治療後急性増悪について 臨床病理学的に retrospective に検討した．結果． IP 合併肺癌は 39 例（5\%）に認めた．治療後 IP 急性増悪は 39 例中 6 例（15\%）に認め，うち 4 例（10\%）が呼吸不全で死亡した。急性増悪群と非急性増悪群の 2 群間では肺癌治療前の LDH，KL-6， SP-D， $\mathrm{PaO}_{2} ， \% \mathrm{VC}, \% \mathrm{DLco}$ の值には統計学的有意差は認めなかった．治療法別では化学療法 24 例中 5 例 $(21 \%)$ ，手術療法 6 例中 1 例（17\%）に治療後急性増悪を認めた。 IP 分類では，特発性間質性肺炎（idiopathic interstitial pneumonias (IIPs) : idiopathic pulmonary fibrosis (IPF) 29 例, nonspecific interstitial pneumonia （NSIP） 1 例）の 30 例中 4 例（13\%），膠原病随伴性間質性肺炎（collagen vascular disease-IP：CVD-IP）の 9 例中 2 例 $(22 \%)$ に急性増悪を認め, 死亡した 4 例中 2 例は CVD-IP であった． 結語. IIPs のみならず CVD-IPも急性増悪を 念頭に置き肺癌治療にあたることが重要である。（肺癌．2007;47:849-854）

索引用語——肺癌, 間質性肺炎, 急性増悪, 膠原病

\section{Clinical Characteristics of Acute Exacerbation of Interstitial Pneumonia Associated with Lung Cancer After Anti-cancer Treatment}

\author{
Kazutoshi Isobe ${ }^{1}$; Yoshinobu Hata ${ }^{2}$; Keishi Sugino ${ }^{1}$; Go Sano ${ }^{1}$; Yujiro Takai ${ }^{1}$; \\ Kazuhiro Kimura', Chikako Hasegawa ${ }^{3}$; Shuichi Sasamoto ${ }^{2}$; Keigo Takagi2; Sakae Homma ${ }^{1}$
}

\begin{abstract}
Objective. To demonstrate the characteristic clinical features of acute exacerbation of interstitial pneumonia (IP) associated with lung cancer after anti-cancer treatment. Methods. Consecutive 776 cases with lung cancer between June 1999 and April 2007 were retrospectively evaluated to clarify the clinicopathological characteristics of acute exacerbation of IP associated with lung cancer after anti-cancer treatment. Results. Among 776 cases of lung cancer, 39 cases (5\%) had concomitant IP. Acute exacerbation of IP after treatment was found in 6 of the 39 cases $(15 \%)$, and 4 cases (10\%) died of respiratory failure. There were no significant differences in LDH, KL-6, SP-D, $\mathrm{PaO}_{2}$, \% VC, or \% DLco between the acute exacerbation group and the non-acute exacerbation group before anticancer treatment. Of the 6 cases with acute exacerbation of IP after treatment, exacerbation occurred after chemotherapy in 5 out of 24 cases (21\%), and after surgical resection of the lung cancer in 1 out of 6 cases (17\%). Among the 6 cases with acute exacerbation of IP, the subclassification of IP was IPF in 4 and collagen vascular disease-IP (CVDIP) in 2. Among the 4 cases who died of respiratory failure after acute exacerbation of IP, the underlying systemic disease was IPF in 2 and CVD-IP in 2. Conclusion. Both IIPs and CVD-IP should go through the anti-cancer treatment,
\end{abstract}

東邦大学医療センター大森病院 1呼吸器内科, 2呼吸器外科, 3病理.

別刷請求先：磯部和順, 東邦大学医療センター大森病院呼吸器内 科，＝143-8541＼cjkstart東京都大田区大森西 6-11-1 (e-mail: kazutoshiisobe (aol.com).

1Department of Respiratory Medicine, ${ }^{2}$ Department of Chest Surgery, ${ }^{3}$ Department of Pathology, Toho University Omori Medi- cal Center, Japan.

Reprints: Kazutoshi Isobe, Department of Respiratory Medicine, Toho University Omori Medical Center, 6-11-1 Omori-nishi, Ota-ku, Tokyo 143-8541, Japan (e-mail: kazutoshiisobe@aol.com).

Received July 6, 2007; accepted September 18, 2007.

(C) 2007 The Japan Lung Cancer Society 
keeping the possibility of acute exacerbation of IP in mind. (JJLC. 2007;47:849-854)

KEY WORDS — Lung cancer, Interstitial pneumonia, Acute exacerbation, Collagen vascular disease

\section{はじめに}

間質性肺炎 (interstitial pneumonia：以下 IP)には高率 に肺癌を合併することが知られている.1-5 しかし，IP 合 併肺癌症例においては, 手術, 化学療法などの肺癌治療 に伴い致死的な IP の急性増悪が生じうることがあるこ とから，治療法の選択に難渋する場合が多い．IP 合併肺 癌に打ける治療後の IP 急性増悪の実態を明らかにする 目的でサブタイプ別, 治療法別の発症頻度を retrospectiveに検討した。

\section{対象および方法}

1999 年 6 月〜 2007 年 4 月まで当センターで原発性肺 癌で加療を行った 776 例中, IP に合併した肺癌 39 例 （5\%）を対象とした，方法は下記に示す基準に基づき, 臨床病理学的に検討した.

\section{IP のパターン分類}

病理組織学的に usual interstitial pneumonia (UIP) が 確認された場合と胸部 high resolution CT (HRCT)にお いて大きさ $2 \sim 10 \mathrm{~mm}$ 程度の比較的大きさが揃った，壁 の厚い囊胞状病変が集簇した領域（蜂巣肺）が, 両側肺 底部胸膜直下に優位に存在する場合を UIP パターンと し，それ以外を non-UIP パターンとした。

また, idiopathic interstitial pneumonias（IIPs)のうち $\mathrm{CT}$ で両側肺底部の胸膜直下優位の蜂巣肺を有し (1)50 歳 以上, (2) 3 ヶ月以上の緩徐な発症, (3) 3 ヶ月以上の経過, (4)両側肺野の捻髪音の 4 項目中 3 項目を満たす場合 clinical idiopathic pulmonary fibrosis (cIPF) と診断し た. 6

\section{2. 治療後急性増悪の定義}

日本呼吸器学会のガイドラインに従い以下のように定 義した. 6

1）肺癌治療後に 1 ケ月以内の経過で以下の (1) (3)を 満たすものとした

(1)呼吸困難の増強, (2)HRCT 所見で線維化所見+新た に生じたスリガラス除影 +浸潤影, (3)動脈血酸素分圧の 低下（同一条件下で $\mathrm{PaO}_{2} 10$ torr 以上).

2）明らかな肺感染症, 気胸, 悪性腫瘍, 肺塞栓や心不 全を除外する，CRP， LDH の上昇，KL-6， SP-A， SP-D などの上昇を参考所見とした．

\section{3. 統計学的手法}

2 群間の比較検討には unpaired-t 検定を用い, 危険率
$5 \%$ 未満を統計上有意差ありとした.

\section{結 果}

対象症例の背景を Table 1 に示す，男性 34 例，女性 5 例, 平均年齢は 71.5 歳（58～87 歳）であった。組織型は 小細胞癌 10 例, 腺癌 9 例, 扁平上皮癌 13 例, 組織型が 確定できなかった非小細胞癌 6 例, 大細胞癌神経内分泌 腫瘍 1 例であった．臨床病期は I 期 10 例，II 期 3 例，III 期 14 例，IV 期が 12 例であった。喫煙歴は current smoker が 17 例, former smoker が 19 例, never smoker が 3 例であった. 喫煙指数では $960 \pm 686$ と重喫煙者が多 く認められた。

IP のパターン分類では IIPs は 30 例に合併しており， うち cIPF が 21 例, IPF/UIP が 8 例, nonspecific interstitial pneumonia（NSIP)が 1 例であった。また，膠原病随 伴性間質性肺炎 (collagen vascular disease-IP：以下 CVD-IP) は 9 例で，うち rheumatoid arthritis (RA)/UIP が 7 例, systemic sclerosis（SSc)/UIP が 1 例, SSc/nonUIP が 1 例であった（Table 2).

臨床病期および治療では非小細胞肺癌（non-small cell lung cancer : NSCLC) では I 期の 8 例中 5 例, II 期の 3 例中 1 例の， 6 例に肺葉切除が施行されていた。また， 1 例に胸腔鏡検查診断が施行されていた. III 期以降では化 学療法が 18 例中 13 例に施行されていた。 小細胞肺癌 (small cell lung cancer : SCLC) では 10 例全例に化学療 法，胸腔鏡検查診断が 3 例に施行されていた，胸部放射

Table 1. Patient Characteristics

\begin{tabular}{ll}
\hline Age (mean) & $58-87(71.5)$ \\
Gender & \\
$\quad$ Male/Female & $34 / 5$ \\
Performance status & \\
$\quad$ 0/1/2/3/4 & $12 / 21 / 4 / 0 / 2$ \\
Histology & \\
$\quad$ Sm/Ad/Sq/NSCLC/LCNEC & $10 / 9 / 13 / 6 / 1$ \\
Clinical stage & \\
$\quad$ IA/IB/IIA/IIB/IIIA/IIIB/IV & $8 / 2 / 2 / 1 / 3 / 11 / 12$ \\
Smoking history & \\
$\quad$ Current/Former/Never & $17 / 19 / 3$ \\
Brinkman index (mean \pm SD) & $960 \pm 686$ \\
\hline
\end{tabular}

Sm: small cell carcinoma, Ad: adenocarcinoma, Sq: squamous cell carcinoma, NSCLC: non-small cell lung cancer, LCNEC: large cell neuroendocrine carcinoma. 
Table 2. Subclassification of Interstitial Pneumonia and Lung Cancer

\begin{tabular}{lrl}
\hline IIPs & 30 \\
cIPF & 21 (Sm 5, Ad 3, Sq 8, NSCLC 5) \\
IPF/UIP & 8 (Sm 1, Ad 3, Sq 3, LCNEC 1) \\
NSIP & 1 (Sm 1) \\
CVD-IP & 9 \\
RA/UIP & 7 (Sm 1, Ad 4, Sq 1, NSCLC 1) \\
RA/non-UIP & 1 (Sm 1) \\
SSc/UIP & 1 (Sq 1) \\
\hline
\end{tabular}

IIPs: idiopathic interstitial pneumonias, cIPF: clinical idiopathic pulmonary fibrosis, IPF: idiopathic pulmonary fibrosis, UIP: usual interstitial pneumonia, NSIP: nonspecific interstitial pneumonia, CVD-IP: collagen vascular disease-IP, RA: rheumatoid arthritis, SSc: systemic sclerosis.

Table 3. Clinical Stage and Therapy of Lung Cancer

\begin{tabular}{lll}
\hline NSCLC & & \\
I & 8 & OPE 5 , BSC 3 \\
II & 3 & OPE 1, CTx + RTx 1, BSC 1 \\
IIIA & 3 & CTx 3 \\
IIIB & 7 & CTx 5, BSC 2 \\
IV & 8 & CTx 5, BSC 3 \\
SCLC & & \\
LD & 3 & CTx 3 \\
ED & 7 & CTx 7 \\
\hline
\end{tabular}

OPE: operation, BSC: best supportive care, CTx: chemotherapy, RTx: radiotherapy, SCLC: small cell lung cancer, LD: limited disease, ED: extensive disease.

線療法は, 胸椎転移に対して緩和目的の放射線治療が 1 例に施行されていたのみであった（Table 3).

また, best supportive care（BSC）は 9 例 $(23 \%)$ と 高頻度であったそその理由は高齢（77 歳以上）が 3 例, 高齢 + 低肺機能が 1 例, 患者治療拒否が 3 例, 低肺機能 が 2 例であった。

化学療法では first line が 24/39 例（62\%）に施行され ていた．非小細胞癌の regimenでは carboplatin $(\mathrm{CBDCA})+$ docetaxel $(\mathrm{DOC})$ が 7 例と最も多く, 次い で vinorelbine（VRB）単剤が 3 例，その他が 4 例であっ た. 小細胞癌では 8 例に CBDCA + etoposide（VP-16）, 2 例に cisplatin (CDDP) + VP-16 が施行されていた. Second line は 10 例に施行されていた. 非小細胞癌の regimen ではVRB 単剤, CBDCA + DOC, gemcitabine $(\mathrm{GEM})+$ irinotecan $(\mathrm{CPT}-11)$, nimustin $(\mathrm{ACNU})+$ paclitaxel（PAC）が1例ずつであった。小細胞癌は ACNU + PAC が 3 例, amrubicin (AMR), CPT-11,
Table 4. Regimen of Chemotherapy for Lung Cancer

\begin{tabular}{|c|c|c|c|}
\hline \multicolumn{4}{|l|}{ 1st line $(\mathrm{n}=24)$} \\
\hline \multirow{3}{*}{$\begin{aligned} \text { NSCLC: } & \text { CBDCA + DOC } \\
& \text { CDDP + DOC } \\
& \text { UFT }\end{aligned}$} & 7 & VRB & 3 \\
\hline & 1 & $\mathrm{CDDP}+\mathrm{VRB}$ & 1 \\
\hline & 1 & DOC & 1 \\
\hline SCLC: $\quad$ CBDCA + VP-16 & 8 & $\mathrm{CDDP}+\mathrm{VP}-16$ & 2 \\
\hline \multicolumn{4}{|l|}{ 2nd line $(\mathrm{n}=10)$} \\
\hline NSCLC: VRB & 1 & $\mathrm{CBDCA}+\mathrm{DOC}$ & 1 \\
\hline GEM + CPT-11 & 1 & $\mathrm{ACNU}+\mathrm{PAC}$ & 1 \\
\hline SCLC: $\quad$ ACNU + PAC & 3 & AMR & 1 \\
\hline CPT-11 & 1 & ANV & 1 \\
\hline
\end{tabular}

CBDCA: carboplatin, DOC: docetaxel, VRB: vinorelbine, CDDP: cisplatin, VP-16: etoposide, GEM: gemcitabine, CPT-11: irinotecan, ACNU: nimustin, PAC: paclitaxel, AMR: amrubicin, ANV: adriamycin + nimustin + vindesine.

Table 5. Response Rate to First Line Chemotherapy

\begin{tabular}{|c|c|c|}
\hline $\begin{array}{l}\text { NSCLC: } \\
(\mathrm{n}=14)\end{array}$ & $\begin{array}{l}\text { CBDCA + DOC } \\
\text { VRB } \\
\text { Others }\end{array}$ & $\begin{aligned} 43 \% & (\mathrm{PR} \mathrm{3,} \mathrm{SD} \mathrm{2,} \mathrm{PD} \mathrm{2)} \\
0 \% & (\mathrm{SD} 2, \mathrm{PD} 1) \\
0 \% & (\mathrm{SD} 4)\end{aligned}$ \\
\hline & Total & $21 \% \quad(3 / 14)$ \\
\hline \multirow[t]{2}{*}{$\begin{array}{l}\text { SCLC: } \\
(\mathrm{n}=10)\end{array}$} & $\begin{array}{l}\text { CBDCA + VP-16 } \\
\text { CDDP + VP-16 }\end{array}$ & $\begin{aligned} 88 \% & (\mathrm{CR} 2, \mathrm{PR} 5, \mathrm{SD} 1) \\
100 \% & (\mathrm{CR} 1, \mathrm{PR} 1)\end{aligned}$ \\
\hline & Total & $90 \% \quad(9 / 10)$ \\
\hline
\end{tabular}

PR: partial response, SD: stable disease, PD: progressive disease, CR: complete response.

adriamycin + nimustin + vindesine (ANV)が 1 例ずつで あった (Table 4). First line の奏効率は NSCLCでは 21\%（3/14）であり SCLC では 90\%（9/10）であった (Table 5).

治療後 IP 急性増悪症例は 6/39 例 (15\%) で認められ, 4 例が呼吸不全で死亡した. 死亡例のうち 2 例は RA/ UIP 合併肺癌であった. 化学療法後急性増悪を発症した regimen は ACNU + PAC が 2 例で最も多く, その他は $\mathrm{VRB}$ が 1 例, GEM + CPT-11 が 1 例, DOC が 1 例であっ た (Table 6). 手術後の IP 急性増悪は 6 例中 1 例に認め られ，術後 3 日目に発症し死亡の転帰を逆った。急性増 悪の治療ではステロイドパルス療法が 6 例全例で施行さ れたが, 4 例はステロイド抵抗性であった.うち 1 例には 血液浄化療法 (polymyxin B-immobilized fiber column hemoperfusion treatment : PMX-DHP) が施行されてい た.

手術施行例の手術時間, 術中 $\mathrm{FiO}_{2}$, 麻酔法に関して非 急性増悪 5 例と急性増悪 1 例を比較したが急性増悪の誘 因は明らかでなかった (Table 7)。また, 診断目的の胸腔 
Table 6. Cases with Acute Exacerbation $(n=6)$

\begin{tabular}{|c|c|c|c|c|c|c|c|c|c|}
\hline case & age/sex & $\begin{array}{l}\text { c-stage, histological } \\
\text { type (lung cancer) }\end{array}$ & $\begin{array}{l}\text { subclassifi- } \\
\text { cation (IP) }\end{array}$ & $\begin{array}{l}\text { therapy } \\
\text { (IP) }\end{array}$ & $\begin{array}{l}\text { severity in- } \\
\text { dex (IP) }\end{array}$ & $\begin{array}{c}\text { anti-cancer } \\
\text { therapy }\end{array}$ & $\begin{array}{c}\text { duration to } \\
\mathrm{AE}\end{array}$ & $\begin{array}{l}\text { therapy } \\
(\mathrm{AE})\end{array}$ & prognosis \\
\hline 1 & $77 / \mathrm{M}$ & $\begin{array}{c}\text { T1N2M1, stage IV, } \\
\text { Ad }\end{array}$ & cIPF & - & I & $\begin{array}{l}\text { 1st line } \\
\text { CTx } \\
\text { (DOC) }\end{array}$ & $\begin{array}{l}\text { CTx } \\
4 \mathrm{~W}\end{array}$ & $\begin{array}{l}\text { mPSL } \\
\text { pulse }\end{array}$ & improved \\
\hline 2 & $64 / \mathrm{M}$ & $\begin{array}{c}\text { T4N1M0, stage IIIB, } \\
\text { Ad }\end{array}$ & cIPF & - & I & $\begin{array}{l}\text { 2nd line } \\
\text { CTx } \\
\text { (GEM+ } \\
\text { CPT-11) }\end{array}$ & $\begin{array}{l}\text { CTx } \\
10 \mathrm{D}\end{array}$ & $\begin{array}{l}\text { mPSL } \\
\text { pulse }\end{array}$ & improved \\
\hline 3 & $79 / \mathrm{M}$ & $\begin{array}{l}\text { T3N2M1, stage IV, } \\
\text { Sq }\end{array}$ & RA/UIP & $\begin{array}{c}\mathrm{PSL} \\
20 \mathrm{mg} / \mathrm{D}\end{array}$ & I & $\begin{array}{c}\text { 1st line } \\
\text { CTx (VRB) }\end{array}$ & $\begin{array}{l}\text { CTx } \\
4 \mathrm{~W}\end{array}$ & $\begin{array}{l}\text { mPSL } \\
\text { pulse }\end{array}$ & dead \\
\hline 4 & $69 / \mathrm{M}$ & $\begin{array}{c}\text { T1N0M0, stage IA, } \\
\text { Ad }\end{array}$ & RA/UIP & - & I & OPE & $\begin{array}{l}\text { OPE } \\
3 \mathrm{D}\end{array}$ & $\begin{array}{c}\text { mPSL } \\
\text { pulse } \\
\text { PMX-DHP }\end{array}$ & dead \\
\hline 5 & $67 / \mathrm{M}$ & $\begin{array}{l}\text { T2N3M0, stage IIIB, } \\
\text { Sm }\end{array}$ & cIPF & $\begin{array}{c}\text { PSL } \\
20 \mathrm{mg} / \mathrm{D}\end{array}$ & IV & $\begin{array}{c}\text { 2nd line } \\
\text { CTx } \\
\text { (ACNU/PAC) }\end{array}$ & $\begin{array}{l}\text { CTx } \\
1 \mathrm{~W}\end{array}$ & $\begin{array}{l}\text { mPSL } \\
\text { pulse }\end{array}$ & dead \\
\hline 6 & $58 / \mathrm{M}$ & $\begin{array}{l}\text { T2N3M0, stage IIIB, } \\
\text { NSCLC }\end{array}$ & cIPF & - & I & $\begin{array}{c}\text { 3rd line } \\
\text { CTx } \\
\text { (ACNU/PAC) }\end{array}$ & $\begin{array}{l}\text { CTx } \\
11 \mathrm{D}\end{array}$ & $\begin{array}{l}\text { mPSL } \\
\text { pulse }\end{array}$ & dead \\
\hline
\end{tabular}

M: male, PSL: prednisolone, D: days, AE: acute exacerbation, W: weeks, PMX-DHP: polymyxin B-immobilized fiber column hemoperfusion treatment.

Table 7. Comparison of Operation Findings Between AE and Non-AE Cases

\begin{tabular}{|c|c|c|c|c|c|c|c|}
\hline case & age, sex & $\begin{array}{c}\text { p-stage, } \\
\text { histological type }\end{array}$ & operation modality & anesthesia & $\begin{array}{l}\mathrm{FiO}_{2} \text { during } \\
\text { operation }\end{array}$ & operation time & $\mathrm{AE}$ \\
\hline 1 & $69, \mathrm{M}$ & pT1N0M0, Ad & $\mathrm{RLL}+\mathrm{ND} 2$ & TIVA + Epi & $0.80-1.0$ & $3 \mathrm{~h} 30 \mathrm{~m}$ & $(+)$ \\
\hline 2 & $76, \mathrm{M}$ & pT2N0M0, Sq & $\mathrm{RLL}+\mathrm{ND} 2$ & TIVA + Epi & $0.50-1.0$ & $3 \mathrm{~h} 27 \mathrm{~m}$ & $(-)$ \\
\hline 3 & $61, \mathrm{M}$ & pT1N0M0, Ad & $\mathrm{RLL}+\mathrm{ND} 2$ & TIVA + Epi & $0.66-0.75$ & $2 \mathrm{~h} 0 \mathrm{~m}$ & $(-)$ \\
\hline 4 & $65, \mathrm{M}$ & pT1N0M0, Sq & $\mathrm{RLL}+\mathrm{ND0}$ & $\mathrm{IHA}+$ Epi & 1.0 & $1 \mathrm{~h} 40 \mathrm{~m}$ & $(-)$ \\
\hline 5 & $76, \mathrm{~F}$ & pT1N0M0, Ad & $\mathrm{LLL}+\mathrm{ND} 2$ & IHA + Epi & 1.0 & $5 \mathrm{~h} 10 \mathrm{~m}$ & $(-)$ \\
\hline 6 & $76, \mathrm{M}$ & pT1N0M0, Sq & $\mathrm{LUL}+\mathrm{ND} 2$ & $\mathrm{IHA}+\mathrm{Epi}$ & $0.8-1.0$ & $6 \mathrm{~h} 36 \mathrm{~m}$ & $(-)$ \\
\hline
\end{tabular}

RLL: right lower lobectomy, ND2: group 2 node dissection, LLL: left lower lobectomy, LUL: left upper lobectomy, TIVA: total intravenous anesthesia, Epi: epidural anesthesia, IHA: inhalation anesthesia, h: hours, m: minutes.

Table 8. Comparison Between AE Group and Non-AE Group Before Anti-cancer Treatment

\begin{tabular}{lccc}
\hline & $\begin{array}{c}\text { AE group } \\
(\mathrm{n}=6)\end{array}$ & $\begin{array}{c}\text { non-AE group } \\
(\mathrm{n}=33)\end{array}$ & P value \\
\hline $\mathrm{LDH}(\mathrm{IU} / \mathrm{l})$ & $473 \pm 88$ & $500 \pm 184$ & 0.70 \\
$\mathrm{KL}-6(\mathrm{U} / \mathrm{ml})$ & $728 \pm 364$ & $1026 \pm 633$ & 0.20 \\
$\mathrm{SP}-\mathrm{D}(\mathrm{ng} / \mathrm{ml})$ & $141 \pm 140$ & $144 \pm 93$ & 0.95 \\
$\mathrm{PaO}($ torr $)$ & $84 \pm 18$ & $74 \pm 13$ & 0.13 \\
$\% \mathrm{VC}(\%)$ & $89 \pm 13$ & $96 \pm 22$ & 0.43 \\
$\% \mathrm{DLco}(\%)$ & $64 \pm 20$ & $54 \pm 20$ & 0.27 \\
\hline
\end{tabular}

鏡検査が 4 例に施行されたが, 急性増悪は生じなかった. さらに 39 例中 6 例の急性増悪群と 33 例の非急性増悪 群の 2 群間において, 肺癌治療前の LDH, KL-6, SP-D, $\mathrm{PaO}_{2}, \% \mathrm{VC}, \% \mathrm{DLco}$ 值を比較したが統計学的
有意差は認められなかった（Table 8).

\section{考察}

IP には進行性に呼吸不全に至るだけでなく, 経過中に 気道感染や外傷, 外科的侵襲を契機に急性増悪を引き起 こし致命的な結果を招く，極めて予後不良の疾患群が含 まれる. ${ }^{1}$ IP 急性増悪の発症機序は, 一つの仮説として, 線維化刺激に反応しやすい状態の患者に, 全身性のサイ トカイン血症が引き金となると考えられている. ${ }^{1}$

また, IP, 特に IPF は高率に肺癌を合併することが知 られており $8.7 〜 36 \%$ と報告されている. $2-5$ 当科におけ る肺癌症例の IP 合併頻度は $5 \%$ であり, 病期ごとの治療 方法は IP 合併のない原発性肺癌とほぼ一致しているが, 低肺機能や高齢などの理由より肺癌治療の適応なしとさ れ，39 例中 9 例 $(23 \%)$ にBSC が施行されていた. 
IIP 合併肺癌の治療後急性増悪の発生頻度は化学療法 が 8.7 $11.5 \%$, 放射線治療が $25 \%$, 化学療法 +放射線療 法が 23.1 36.4\%, 手術療法が 12.5 22\%, と報告されて いる.7-11 本検討では化学療法後は 24 例中 5 例 $(21 \%)$,

手術後は 6 例中 1 例 $(17 \%)$ で，諸家の報告と比較する と化学療法後の発症がより高頻度で, 術後の発症は諸家 の報告と一致していた.

術後の IP 急性増悪の発症要因には(1)術前の間質性肺 炎の高い活動性，(2)術中高濃度酸素，(3)長時間の手術侵 襲などが挙げられる. ${ }^{12}$ IP 合併肺癌における術後の急性 増悪の予防としては, 高濃度の酸素曝露の回避の他に, erythromycinの術前投与が有効であるとの報告13 や, 手術期におけるステロイド投与の有効性を示している報 告14もあるものの確立された予防方法はない. さらに, 周術期のステロイド剤の投与に関しては, 術前投与や減 量が術後急性増悪を惹起するとの報告もあり, 2,15 予防 投与したステロイド剂は減量自体のリスクがある.この ため, 手術施行の 6 例にはステロイドの予防投与は行っ ていない. また, 当科の化学療法においてのステロイド 剤は betamethasone 4〜8 mg/body を抗癌剤投与日のみ に投与している.これは IP 非合併例の化学療法と同用量 である.このようなステロイド剤の単回投与が IP 急性増 覀の発症因子となりうるかは明らかでない. 今回術後の 急性増悪を認めた 1 例では手術時間や術中 $\mathrm{FiO}_{2}$ でも明 らかな誘因は認められなかった．現時点では術後の急性 増悪を予防する具体的な方法は確立されておらず, 術前 の十分な IP の活動性の評価に加え, 呼吸器外科医, 麻酔 科医, 呼吸器内科医との十分な連携が必要である.

化学療法では, CDDP はVP-16 P VRB との併用で致 死的肺障害が認められ, 多剂併用療法での危険性が指摘 されている. 16 さらに使用薬剤ではGEM, CPT-11, AMR は投与禁忌, VRB, DOC, PAC, gefitinib は慎重 投与と薬剤添付文書に記載されている. ${ }^{2}$ 本検討でも化 学療法後に IP 急性増悪を発症した 5 例全例にこれらの 抗癌剂が使用されていた. 肺小細胞癌に対する CBDCA + VP-16 は諸家の報告, ならびに本検討をみても 急性増悪例は少なく, 比較的安全と考えられる. しかし, second line 以降の抗癌剤で, 効果, 副作用の面を考慮し て推奨される抗癌剤はないことが現時点の問題点であ る. 非小細胞肺癌では IP 合併例には慎重投与である DOC, PAC, VRB などとプラチナ製剤との併用が最も多 用されている regimenであることが問題点として挙げ られる. 禁忌薬剤を使用する際には CT 上で IP の合併の 有無の確認が重要である.

IP の急性増悪の発症の危険因子として従来より $\mathrm{CRP}, \mathrm{LDH}, \mathrm{WBC}$ などの上昇や, $\mathrm{PaO}_{2}, \% \mathrm{VC}$ の低下 などが報告されている.9,17,18 しかし, 本検討では急性増
悪群と非急性増悪群の 2 群間で肺癌治療前の LDH, KL-6, SP-D, $\mathrm{PaO}_{2}, \% \mathrm{VC}, \% \mathrm{DLco} の$ 值に統計学的有 意差は認められなかった. 症例数が少ないことも一因と 考えられるが, IP の活動性を示す KL-6 は腫瘍マーカー としての側面を持ち, SP-D も肺癌に発現することがある ので, IP のみの活動性の評価が困難である点も挙げられ る. 19,20 以上より治療前における IP 急性増悪の予測は困 難であることが示唆された.

また，本検討では， CVD-IP 合併肺癌の 9 例のうち 2 例 $(22 \%)$ に急性増悪を認めている。これはIIPsの 30 例中 4 例 $(13 \%)$ より高い割合であった. CVD-IP に肺癌 を合併する頻度は 2 4\% と報告されているが, 21 辻田ら の報告では 155 例中 19 例（12\%） と報告されている. 22 CVD-IP は IIPs に比較して急性増悪を起こす頻度は少な いものの, 膠原病の死因のうち IP が占める割合は $37.5 \%$ と高いことが報告されている. ${ }^{23}$ CVD-IP の急性増悪の 報告はシェーグレン症候群, RA, SSc, systemic lupus erythematosus, polymyositis/dermatomyositis な゙で 散見されるが, ${ }^{24-28}$ CVD-IP に合併した原発性肺癌に関 する検討はほとんどない. また, RA/UIP の急性増悪は 一般的に治療抵抗性であるとされ, 29 富山ら 25 もステロ イドパルス療法に抵抗性の RA/UIP の急性増悪症例を 報告している. 本検討でも IP 急性増悪を発症した 4 例中 2 例はいずれも RA/UIP であり, 一旦急性増悪した後は ステロイド抵抗性で極めて予後不良であった.

以上, IP 合併肺癌において, IIPs のみならず CVD-IP も急性増悪を生じうることを念頭に置き治療すべきであ ると考えられた。

\section{REFERENCES}

1. 青山克彦, 星 永進, 生方幹夫, 高柳 昇, 河端美則, 金 沢 実, 他. 特発性間質性肺炎の臨床. 肺癌の合併とその 対応. 日本胸部臨床. 2003;62:S114-S120.

2. 竹内栄治, 山口俊彦, 森 雅秀, 田中茂治, 中川 勝, 横 田総一郎, 他. 肺癌を合併した特発性間質性肺炎症例の臨 床的検討. 日本胸部疾患学会雑誌. 1996;34:653-658.

3. 大塚義紀, 浮田英明, 正木芳孝, 土肥 勇, 棟方 充, 川 上義和，他. 特発性間質性肺炎 (IIP) からの肺癌発症一 prospective study一. 日本胸部疾患学会雑誌. 1991;29:560565.

4. 饗庭三代治, 内田和仁, 稲富恵子, 本間日臣. 特発性間質 性肺炎と肺癌合併症例の背景因子と治療の問題点. 肺癌. 1985;25:617-623.

5. 谷村一則, 清水 透, 本間行彦, 小笠原英紀, 日下大隆, 井上幹朗, 他. 特発性間質性肺炎と肺癌合併例の特徵, と くに頻度, 組織型, 発生部位, 病期, 年歯令, 肺機能につい て. 日本胸部疾患学会雑誌. 1987;25:216-221.

6. 特発性肺線維症 (IPF) の急性増悪. 特発性間質性肺炎診 断と治療の手引き。日本呼吸器学会びまん性肺疾患診 断・治療ガイドライン作成委員会, 編集. 東京 : 南江堂 ; 
2004:36-40.

7. 朝田完二, 鈴記好博, 向井順之輔, 大串文隆, 曽根三郎, 小倉 剛. 特発性間質性肺炎を合併した肺癌症例の臨床 的検討. 日本胸部臨床. 1992;51:214-219.

8. 岡田大輔, 小泉 潔, 川本雅司, 逸見しのぶ, 平井恭二, 三上 厳, 他. 特発性間質性肺炎合併肺癌における術後急 性増悪の臨床病理学的検討。肺癌. 2002;42:567-572.

9. 竹中 圭, 吉村明修, 岡野哲也, 清家正博, 神尾孝一郎, 植松和嗣，他. 特発性間質性肺炎 (IIP) 合併肺癌におけ る肺癌治療に伴う IIP 急性増悪の検討. 肺癌. 1999;39:955962.

10. 埴淵昌毅, 山口俊彦, 岡田達也, 中川 勝, 横田総一郎, 伊藤正己，他． 特発性間質性肺炎（IIP）合併肺癌に対す る肺癌治療後 IIP 急性増悪症例の臨床的検討. 肺癌. 2001; 41:281-286.

11. 谷村繁雄, 友安 浩, 伴場次郎, 正木幹雄, 中田紘一郎, 松下 央, 他. 特発性間質性肺炎に合併した肺癌に対する 手術の検討。日本胸部臨床．1992;51:208-213.

12. 坂本 晋, 本間 栄, 川畑雅照, 河野 匡, 関 邦彦, 中 田紘一郎, 他. 肺癌術後の対側肺からの急性増悪を確認 $し え た i d i o p a t h i c$ pulmonary fibrosis/usual interstitial pneumonia の 1 剖検例. 日本呼吸器学会雑誌. 2004;42: 760-766.

13. 杉山幸比古. エリスロマイシン療法の進展について. 日本 胸部臨床. 1995;54:57-62.

14. 工藤翔二, 川俣仲秋, 家城隆次, 後藤 元, 堀之内宏久, 池田高明, 他. 特発性間質性肺炎合併肺癌の治療に関する レトロスペクティブな検討 : 特に術後急性増悪と予防の 可能性について. 厚生省特定びまん性肺疾患調査研究班, 平成 3 年度研究報告書. 1992:78-80.

15．野本幸子．間質性肺炎患者の術後急性増悪例．臨床麻酔． 1991;15:1427-1430.

16. 佐川元保, 斎藤泰紀, 高橋里美, 薄田勝男, 菅間敬治, 佐 藤雅美, 他. CDDP, MMC, CPM 併用療法により惹起され た間質性肺炎．癌の臨床．1988;34:150-154.

17. 中川勝裕, 安光 勉, 古武弥宏, 上島成幸, 敷尾 展, 種 村匡弘, 他. 特発性間質性肺炎を伴った肺癌手術症例の検 討. 日本胸部外科学会雑誌. 1994;42:1933-1939.
18．塚本克紀，千田金吾，早川啓史，佐藤篤彦，中島康雄，土 井 修, 他. 急性増悪を呈した特発性間質性肺炎(慢性型) の臨床像の検討. 日本胸部疾患学会雑誌. 1997;35:746-754.

19. 高橋弘毅, 白鳥正典, 猪俣慎一郎. びまん性肺疾患の疾患 活動性マーカー。内科. 2007;99:218-222.

20. 本間 栄, 中田紘一郎. びまん性間質性肺炎における血清 soluble interleukin-2 receptor 值測定の意義. 呼吸. 2001; 20:308-313.

21. Yang Y, Fujita J, Tokuda M, Bandoh S, Ishida T. Lung cancer associated with several connective tissue diseases: with a review of literature. Rheumatol Int. 2001;21: 106-111.

22. 辻田章博, 大野彰二, 細野達也, 小林 晃, 坂東政司, 杉 山幸比古．膠原病関連間質性肺炎に合併した肺癌の治療 戦略. 肺癌. 2006;46:467.

23. 滝沢 始, 鈴木直仁, 柳川 崇, 岡崎 仁, 佐藤 誠, 秋 山法久, 他. 膠原病における間質性肺病変の重要性一生命 予後の解析から一. 日本胸部疾患学会雑誌. 1996;34:11771181.

24. 成瀬代士久, 乾 直輝, 安井秀樹, 柄山正人, 山菩佐和, 村松江里子, 他. 急速に呼吸不全が進行した原発性シェー グレン症候群に伴った間質性肺炎の 1 例. 日本呼吸器学 会雑誌. 2006;44:721-726.

25. 富山 洋, 高良 到, 徳嶺譲芳, 須加原一博. ステロイド パルス療法無効の ARDS に対してシベレスタットが奏 効した慢性関節リウマチ急性増悪の 1 症例。麻酤. 2004; 53:1042-1046

26. 本間 栄. 膠原病肺の急性増悪例の呼吸管理の症例一ス テロイドパルス，免疫抑制薬一. 治療学. 2003;37:12061209.

27. 定形綾香, 山口正雄, 三崎義堅, 小宮明子, 黨 康夫, 飯 倉元保，他. 間質性肺炎を伴うRAの経過中, SLE 発症 と同時に肺病変の急性増悪をきたした 1 例。日本呼吸器 学会雑誌. 2002;40:756-761.

28. Lee CS, Chen TL, Tzen CY, Lin FJ, Peng MJ, Wu CL, et al. Idiopathic inflammatory, myopathy with diffuse alveolar damage. Clin Rheumatol. 2002;21:391-396.

29. 土肥 眞. 関節リウマチ。治療学. 2006;40:1175-1179. 